\title{
İşitme Yetersizliğine Sahip Öğrencilerin Dinleme Becerilerini Geliştirmeye Yönelik Sınıf Öğretmenlerinin Görüşlerinin İncelenmesi
}

\author{
Assessment of the Opinions of the Classroom Teachers in \\ Developing Listening Skills of Hearing Impaired Students
}

\author{
Gülcihan (HASANOĞLU) YAZÇAYIR* \\ M. Cem GIRGIN*
}

• Geliş Tarihi: 27.03.2018 • Kabul Tarihi: 02.11.2018 • Yayın Tarihi: 01.01.2019

\begin{abstract}
$\ddot{O} \mathbf{z}$
$\mathrm{Bu}$ araştırmanın amacı; kaynaştırma eğitimine dahil olan işitme yetersizliğine sahip öğrencilerin dinleme becerilerini geliştirmeye yönelik sınıf öğretmenlerinin görüşlerinin incelenmesidir. Araştırmanın modeli betimsel taramadır. Araştırmada veri toplama aracı olarak araştırmacılar tarafindan geliştirilen "İşitme Yetersizliğine Sahip Öğrencilerin Dinleme Becerilerini Geliştirmeye Yönelik Öğretmen Görüşleri Ölçeği” kullanılmıştır. Aynı zamanda bu ölçeğe iki tane açık uçlu soru eklenerek yazılı görüş alınmıştır. Öğretmenlerin işitme yetersizliğine sahip öğrencilerin dinleme becerilerini geliştirmeye yönelik görüşleri 6-10 yıllık kıdeme sahip öğretmenler ile 11-20 yıllık kıdeme sahip öğretmenler arasından bakıldığında 11-20 yıllık kıdeme sahip öğretmenlerin lehine anlamlı farklılık göstermektedir. Öğretmenlerin çoğunluğunun işitme yetersizliğine sahip öğrencilerin eğitimine dair yeterli eğitim almadıkları ve kendi öğrencilerine destek eğitim sağlamadıkları belirlenmiştir. Sınıf öğretmenlerinin işitme yetersizliğine sahip öğrencilerinin dinleme becerilerini geliştirmeye yönelik görsel materyal kullanma, fiziksel düzenleme, derse katılımını sağlama, konuşma hızı, tonu, göz teması kurma, şiir, şarkı, drama katılımı gibi uygulamalar yaptığı belirlenmiştir. Öğretmenler en çok öğrencilerinin iletişim becerilerini geliştirme konusunda yardıma ihtiyaç duymaktadırlar.
\end{abstract}

Anahtar sözcükler: Dinleme, işitme yetersizliği, sınıf öğretmenleri, kaynaştırma

\section{Önerilen Atıf Bilgisi:}

Yazçayır, G.H. ve Girgin, M.C. (2019). İşitme yetersizliğine sahip öğrencilerin dinleme becerilerini geliştirmeye yönelik sınıf öğretmenlerinin görüşlerinin incelenmesi. Pamukkale Üniversitesi Eğitim Fakültesi Dergisi, 45, 56-77.

*Bu çalışmanın bir kısmı 27-29 Nisan 2017 tarihinde Çanakkale'de gerçekleştirilen VII. Uluslararası Eğitimde Araştırmalara Kongresi'nde (ULEAD-2017) sözlü bildiri olarak sunulmuştur.

**Araş. Gör., Uşak Üniversitesi, Eğitim Fakültesi, Özel Eğitim Bölümü, Uşak-TÜRKİYE, ORCID: 0000-0001-50941237,gulci_h35@hotmail.com, .

***Prof. Dr., Anadolu Üniversitesi, Eğitim Fakültesi, İşitme Engelliler Engelliler Bölümü, Eskişehir-TÜRKIYYE, ORCID: 0000-0003-2522-1953, mcgirgin@ gmail.com, . 


\title{
İşitme Yetersizliğine Sahip Öğrencilerin Dinleme Becerilerini Geliştirmeye Yönelik Sınıf Öğretmenlerinin Görüșlerinin İncelenmesi
}

\begin{abstract}
The aim of this study was to determine primary school teachers' opinions on improving listening skills of students with hearing impaired who are included in their classrooms through inclusion education. The model of the research is a descriptive scan. Data were collected using "The Teacher Opinion Scale for Developing Listening Skills of Students with Hearing Impaired" developed by the researchers. At the same time, two open-ended questions were added to this scale and a written opinion was obtained. The teachers' opinions about improving the listening skills of their students with hearing impaired differed significantly in favor of those teachers with 11-20 years of seniority between teachers with 6-10 years of seniority and 11-20 years of seniority. The majority of the teachers did not receive adequate training on teaching students with hearing impaired and they did not provide support education to their students. It has been determined that the students with hearing impaired of classroom teachers are doing applications such as using visual material, physical arrangement, providing class participation, speaking speed, tone, eye contact, poetry, song and drama participation to improve listening skills. Teachers need help to improve the communication skills of their students.
\end{abstract}

Key words: Listening, hearing impaired, primary school teachers, inclusion

\section{Giriş}

İşitme ve dinleme terimleri günlük konuşmada birbirlerinin yerine kullanılsa da, aralarında önemli farklılıklar vardır. Her ikisi de ses algılamasıyla başlarken, aralarındaki temel fark bir amaç derecesidir. Başlangıçta amaç, uzak bir kaynağın sezilmesi ve bu kaynaktan etkilenme isteğidir. İşitme, dinleme için bir temel sağlarken, aynı zamanda dinlemenin öncüsüdür (Rost, 2011). İşitme, işitme teknolojilerinden faydalanılarak, çevrenin düzenlenilerek ve ses gürültü oranının iyileştirilerek seslerin beyne ulaşma sürecidir. Dinleme becerilerinin gelişebilmesi için önce sesle ilgili olayların beyne iletilmesi gerekir (Cole \& Flexer, 2007). İşitme ve dinleme için dilimizi ve çevremizdeki dünyayı anlamamızın temelini oluşturan karmaşık fizyolojik süreçlerdir denilebilir. Aynı zamanda, işitme ve dinlemenin fizyolojik sistemlerin çok ötesine geçen, fiziksel olmayan işleme ve anlama yönleri bulunmaktadır. Bireysel ve evrensel algı ve deneyim arasındaki bu nörolojik- bilişsel köprüyü tanımlamak için sıklıkla kullanılan kavram bilinçtir. Bilinç; dikkati başlatan, anlamı inşa eden, hafıza ve öğrenme gibi süreçleri tanımlamak için kullanılan kök kavramdır. Dinlemeyi açıklarken bilinç kavramı çok önemlidir (Chafe, 2000; Rost, 2011). Dinlemede, ses ile ilgili olaylara bilinçli olarak katılım vardır (Cole \& Flexer, 2007).

Herkes konuşmadan, okumadan ya da yazmadan önce dinlemiştir (Palmer, 2014). Yeni dünyaya gelen bebekler herhangi bir dili öğrenme kapasitesi ile dünyaya gelirler (Robinshaw, 2007). Dili öğrenmek dinleme yoluyla başlamaktadır (Cochlear Limited, 2005; Rhoades, 2011). Çocuk dünyaya geldikten sonra çevresini dinleyerek konuşmayı öğrenir ve çevresi ile iletişim kurar (Cochlear Limited, 2005; Easterbrooks \& Estes, 2007). İletişim sürecinin en temel ögesi dinleme; bireysel ve toplumsal ilişkilerde başarılı olmanın da ön şartıdır. Dinleme becerisinin gelişmesi; empati kurabilen, problem çözme becerileri, özgüvenleri, kendilerine yönelik algıları gelişmiş bireyler yetişmesinde önemli rol oynar (Funk \& Funk, 1989).

Yıllar geçmesine rağmen hala işitme yetersizliğine sahip çocukların sağır ve dilsiz olduğuna dair yanlış algılar mevcuttur. Gelişen teknoloji ve erken müdahale sayesinde işitme yetersizliğine sahip çocuklar anlamlı seslere ulaşmada, konuşma dilinin, okumanın ve akademik becerilerinin gelişiminde normal işitenler ile aynı fırsata sahip olabilmektedirler (Cole \& Flexer, 2007; Gárate \& Lenihan, 2016; Rhoades, 2011). İşitme cihazları, koklear implantlar ve FM sistemi gibi yardımcı sistemler işitme kaybı olan çocuğun işitsel bilgi girdilerini alarak eğitim 
sürecine katılma yeteneklerini geliştirir (Anderson, Goldstein, Colodzin, Inglehart, 2005; Cochlear Limited, 2005; Estabrooks, 2006; Tüfekçioğlu, 1992). Koklear implant olan birçok çocuk, normal işiten akranları ile aynı ortamlarda eğitim almalarına ve sözel iletişim kurmalarına olanak tanıyan dil becerilerini geliştirmektedir (Geers, Moog, Biedenstein, Brenner \& Hayes, 2009). Son y1llarda yenidoğan tarama testleri, erken müdahale, koklear implant olan çocuk sayısının artması ve özel eğtimde devlet politikaları sayesinden işitme yetersizliği olan bireylerin genel eğitim sınıflarında normal gelişim gösteren akranları ile birlikte eğitim almaları yaygınlaşmıştır (Luckner \& Muir, 2001; Turnbull, Turnbull, Wehmeyer \& Shogren, 2013).

Özel gereksinimli öğrencilerin normal gelişim gösteren akranları ile genel eğitim ortamında çeşitli program ve ortam düzenlemeleri yapılarak eğitimini sürdürmesine kaynaştırma olarak tanımlanmaktadır (Ainscow, 2005; Heward, 2013; Lindsay, 2007; Salend, 2005; Turnbull, Turnbull, Wehmeyer \& Shogren, 2013). Buna bağlı olarak işitme yetersizliğine sahip çocukların normal gelişim gösteren akranları ile genel eğitim sınıflarında eğitim ihtiyaçlarını karşılamak için de çok yönlü düzenlemeler gereklidir. Eğitim ortamlarının temel uygulayıcısı öğretmelerin işitme yetersizliği olan öğrencisinin gereksinimlerine bağlı olarak program hazırlaması, öğrenme öğretme etkinliklerini düzenlemesi, fiziksel düzenlemeler yapmas1, öğrenme ve gelişme firsatları sağlaması, akranları ile olumlu iletişim geliştirmesine destek olmas1 gerekmektedir (Avramidis \& Norwich, 2002; Eriks-Brophy \& Whittingham, 2013; Mastropieri \& Scruggs, 2014; Salend, 2005; Turnbull, Turnbull, Wehmeyer \& Shogren, 2013). Sınıf öğretmenlerinin öğrencilerine destek olabilmeleri için öncelikle gerekli bilgi ve beceriye sahip olmaları ya da eğitim almaları gerekmektedir (Funk \& Funk, 1989; Palmer, 2014). En temelde öğretmenlerin bir konuyu etkili bir biçimde öğretebilmesi ve öğrencileri ile sağlıklı bir iletişim kurabilmesi öğrencilerine etkili dinleme becerileri kazandırmasına bağlıdır (Funk \& Funk, 1989). Etkili dinleme becerilerinin kazandırılması ve öğrenme için öncelikle olumlu bir dinleme ortamı gereklidir (Cole \& Flexer, 2007; Estabrooks, 2006; Knecht, Nelson, \& Whitelaw, 2002).

Sağlıklı bir dinleme ortamının önemli bir etkeni gürültü ses oranı dengesidir (Girgin, 2006). Dersliklerde dışarıdan gelen sesler, derslikte bulunan araç gereçlerin çıkardıkları sesler ya da öğrenci sesleri gürültüye neden olabilir. Bu seslerin duvarlardan, tavandan, masadan, tahtadan yansıması gürültüyü arttırabilir (Turan, 2007). Konuşma sinyallerinin anlaşılırlığı için sesin yansımasının 0.4 ile 0.8 saniyeden fazla olması dinlemeye olumsuz etki eder (Dockrell \& Shiels, 2006). Bunların yanı sıra, sesin kaynağından uzaklaştıkça sesin gücü azalır. Bu dersliklerde göz önünde bulundurulması gereken önemli diğer bir faktördür. Bir öğretmenin sesinin seviyesi yaklaşık $10 \mathrm{~dB}$ kadar yükseldiğinde $1 \mathrm{~m}$ uzaklıkta işitilebilirliği 60-65 dB'dir. $\mathrm{Bu}$ demek oluyor ki sınıfta en ön sıralarda oturan öğrenciler öğretmenin sesini $65 \mathrm{~dB}$ 'de işitebilir, konuşma sinyallerinin ortalama \% 83'ünü algılayabilir, \%95 kelimeyi tanımayı başarabilirler. Konuşmacı dinleyiciden uzaklaştıkça ortalama $6 \mathrm{~dB}$ işitilebilirliği azalır ve buna bağlı olarak konuşma sinyallerini algılama ile kelime tanıma oranı da azalır. Çocukların yetişkinlerde olduğu gibi boşlukları tamamlama tecrübesi olgunlaşmadığ 1 için konuşmada duymadıkları kelimelerin \%40'1nı tamamlayamazlar (Crandell \& Smaldino, 2000; Siebein, Gold, Siebein, \& Ermann, 2000; Robinshaw, 2007). Tüm bu nedenler göz önünde bulundurulduğunda sadece işitme yetersizliğine sahip öğrenciler için değil aynı zamanda tüm öğrenciler için etkili bir dinleme ortamının öğrenme için önemli bir yeri olduğundan söz edilebilir. 


\section{İşitme Yetersizliğine Sahip Öğrencilerin Dinleme Becerilerini Geliştirmeye Yönelik Sınıf Öğretmenlerinin Görüșlerinin İncelenmesi}

Uluslarası alanyazında Rekkedal (2015) tarafından öğrencilerin ve öğretmenlerin görüşlerine dayalı olarak, işitme engelli öğrencilerin sınıf içi iletişim ve dinleme algılamalarıyla ilişkili faktörleri araştırılmıştır. Ailesi eğitim sürecine dahil olan işitme yetersizliğine sahip öğrencilerin iletişim becerilerinin daha gelişmiş olduğu ve mikrofon gibi sınıf içi yardımcı teknoloji kullanımının işitme yetersizliğine sahip öğrencilerin dinleme algılarına olumlu etki ettiği belirlenmiştir. Eriks-Brophy \& Whittingham (2013) tarafindan yapılan bir araştırmada, genel eğitim sınıf öğretmenlerinin işitme yetersizliğine sahip öğrencilerin genel eğitim sınıflarında öğrenim görmesi hakkında olumlu görüsse sahip oldukları ve işitme yetersizliğine sahip öğrencilerin kullandığı işitmeye yardımcı cihazları (işitme cihazları, koklear implant, FM veya diğer yardımcı dinleme cihazları) hakkındak bilgi sahibi oldukları belirlenmiştir. Doğan \& Özçakmak (2014) ise 1998-2013 yılları arasında ulusal tez veri tabanında yer alan dinleme eğitimi konusunda yapılan yüksek lisans ve doktora tezlerini çeşitli değişkenlere göre değerlendirmişlerdir. Çalışma kapsamında yer alan araştırmalarda hedef kitlelerin sadece farklı eğitim kademelerinde yer alan normal gelişim gösteren öğrenciler olduğu anlaşılmıştır. Ulusal alan yazındaki dinleme becerisinin gelişimine yönelik yapılan birçok çalışmada işitme yetersizliğine sahip öğrencilere yer verilmediği anlaşılmıştır (Ciğerci, 2015; Doğan, 2007; Durmuş, 2013; Koç, 2003). Akçakaya \& Tavşancıl (2016)'ın işitme yetersizliğine sahip öğrencilerle yürütülen işitsel sözel terapi uygulamasına dair öğretmen görüşlerine yer verdiği çalışmasının bulgularında dinleme becerilerindeki gelişmelerin dil gelişimine olumlu etkileri olduğuna dair ifadeler yer almaktadır. Ek olarak tüm öğretmenlerin, işitsel algı, dil gelişimi, konuşma üretimi ve konuşmanın anlaşılabilirliğinin, dinleme gelişiminden olumlu etkilendiğini ifade ettikleri raporlanmıştır. Öte yandan ulusal alanyazında işitme yetersizliğine sahip öğrencilerin dinleme becerilerinin gelişimine yönelik sınırlı sayıda araştırma bulunmaktadır. Aynı zamanda, genel eğitim sınıf öğretmenlerinin kaynaştırma eğitimine dahil olan işitme yetersizliğine sahip öğrencilerinin dinleme becerilerini geliştirmeye yönelik görüşlerinin belirlenmesine ilişkin bir çalışmaya da rastlanmamıştır. Bu çalışma, sınıf öğretmenlerinin kaynaştırma eğitimi uygulamalarına dahil olan işitme yetersizliğine sahip öğrencilerinin dinleme becerilerini geliştirmeye yönelik görüşlerine deneyim yıll, öğrencilerine destek eğitim sağlama, bu öğrencilerin öğretimi hakkında eğitim alıp almama gibi değişkenlerin etkisi, öğretmenlerin dinleme becerisinin gelişimine yönelik yaptıkları uygulamaların belirlenmesi ve ortaya konulması bakımından önemlidir. Ortaya çıkan sonuçlardan yola çıkarak süreçte var olan aksaklıkların çözümüne yönelik önerilerin sunulmasına bağlı olarak alanda uygulama yapan öğretmenlere yol gösterici olacağı düşünülmektedir. Öte yandan bu çalışmada, sınıf öğretmenlerinin işitme yetersiliğine sahip öğrencilerinin dinleme becerilerini geliştirmek için en çok hangi konuda yardıma ihtiyaç duyduklarının belirlenmesi yoluyla bu konularda yeni araştırmaların ve uygulamaların yapılmasına katkı sağlayabilir.

Araştırmanın amacı; sınıfında kaynaştırma eğitimine dahil olan işitme yetersizliğine sahip öğrencilerin dinleme becerilerini geliştirmeye yönelik öğretmen görüşlerini incelemektir. $\mathrm{Bu}$ amaç doğrultusunda "Sınıfında kaynaştırma eğitimine dahil olan işitme yetersizliğine sahip öğrencilerin dinleme becerilerini geliştirmeye yönelik öğretmen görüşleri nelerdir?” soeusuna cevap aranmıştır. Problem cümlesindeki sorunun yanıtını alabilmek için oluşturulan alt problem cümleleri şöyledir: 
1) Sınıf öğretmenlerinin kaynaştırma eğitimine dahil olan işitme yetersizliğine sahip öğrencilerinin dinleme becerilerini geliştirmeye yönelik görüşleri mesleki kıdem bakımından farkl111k göstermekte midir?

2) Sınıf öğretmenlerinin kaynaştırma eğitimine dahil olan işitme yetersizliğine sahip öğrencilerinin dinleme becerilerini geliştirmeye yönelik görüşleri destek eğitim sağlama bakımından farklılık göstermekte midir?

3) Sınıf öğretmenlerinin kaynaştırma eğitimine dahil olan işitme yetersizliğine sahip öğrencilerinin dinleme becerilerini geliştirmeye yönelik görüşleri işitme yetersizliğine sahip öğrenciler hakkında eğitim alma bakımından farklılık göstermekte midir?

4) Sınıf öğretmenlerinin kaynaştırma eğitimine dahil olan işitme yetersizliğine sahip öğrencilerinin dinleme becerilerini geliştirmeye yönelik uyguladıkları yöntemler nelerdir?

5) Sınıf öğretmenlerinin kaynaştırma eğitimine dahil olan işitme yetersizliğine sahip öğrencilerinin dinleme becerilerini geliştirmeye yönelik yardıma ihtiyaç duydukları konular nelerdir?

\section{Yöntem}

\section{Araştırmanın Modeli}

Araştırma betimsel tarama modeli olarak tasarlanmıştır. Betimsel tarama, genellikle yazılı bir ölçek veya yetenek testi şeklinde hazırlanmış formlarda olup çok sayıda bireyin aynı sorulara yanıt vermesini içerir (Frankel \& Wallen, 2009). Bu model yoluyla araştırmacılar tarafından hazırlanan ölçek yoluyla araştırmada sınıf öğretmenlerinin kaynaştırma eğitimine devam eden işitme yetersizliğine sahip öğrencilerinin dinleme becerilerini geliştirmelerine etki eden değişkenler, kullandıkları yöntemler ve yardıma ihtiyaç duydukları konular belirlenmeye çalışılmıştır.

\section{Evren ve Örneklem}

Evren, araştırma sonuçlarının genellemek istendiği bütündür. Ancak büyüyen evrenin maliyet ve kontrol güçlükleri nedeniyle örneklem alma yöntemine başvurulmaktadır (Karasar, 2003). Bu araştırmanın evreni sınıfında kaynaştırma uygulamaları kapsamında işitme yetersizliğine sahip sınıf öğretmenleri oluşturmaktadır. Araştırmanın örneklemi ise Bursa ilinde işitme yetersizliğine sahip öğrencileri olan 118 kaynaştırma eğitimi veren ilkokul düzeyinde sınıf öğretmenleridir. Ancak 118 öğretmenin 3 tanesine ulaşılamamış ve 2 tanesi formu yanıtlamamıştır. Buna bağlı olarak 113 öğretmenden alınan veriler üzerinde çalışılmıştır. Tablo 1'de bu 113 örneklem grubunun deneyim yılına göre dağılımı görülmektedir.

Tablo 1. Örneklem grubunun deneyim yılına göre dağılımı

\begin{tabular}{lcc}
\hline Deneyim yıli & Frekans & Yüzde \% \\
\hline $1-5$ & 7 & 6,2 \\
$6-10$ & 23 & 20,4 \\
$11-20$ & 54 & 47,8 \\
$21+$ & 29 & 25,7 \\
Toplam & 113 & 100,0 \\
\hline
\end{tabular}




\section{İşitme Yetersizliğine Sahip Öğrencilerin Dinleme Becerilerini Geliştirmeye Yönelik Sınıf \\ Öğretmenlerinin Görüșlerinin İncelenmesi}

Tablo 1'de görüldüğü gibi 11-20 yıllık deneyime sahip olan sınıf öğretmenleri, örneklemin \%47,8'ini; 21 yıl ve üzeri deneyime sahip öğretmenler örneklemin \%25,7'sini; 6-10 yıllık deneyime sahip öğretmenler örneklemin \%20,4'ünü, 0-5 yıllık deneyime sahip sinıf öğretmenleri örneklemin \%6,2'sini oluşturmaktadır. Aşağıdaki tablo 2'de örneklem grubunun destek eğitim sağlama durumuna göre dağılımına yer verilmiştir.

Tablo 2. Örneklem grubunun destek eğitimi sağlama durumuna göre dağılımı

\begin{tabular}{lcc}
\hline Destek Eğitimi Sağlama & Frekans & Yüzde \% \\
\hline Yok & 89 & 78,8 \\
Var & 24 & 21,2 \\
Toplam & 113 & 100,0 \\
\hline
\end{tabular}

Tablo 2'de görüldüğü gibi örneklem grubunun \%78,8'i işitme yetersizliğine sahip öğrencilerine destek eğitimi sağlamamakta, \%21,2'si destek eğitimi sağlamaktadır. Örneklem grubunun işitme yetersizliğine sahip öğrencilerin eğitimi hakkında eğitim alma durumuna göre dağılımı tablo 3’te sunulmuştur

Tablo 3. Örneklem grubunun işitme yetersizliğine sahip öğrencilerin eğitimi hakkında eğitim alma durumuna göre dağılımı

\begin{tabular}{lcr}
\hline İsitme Yetersizliğine Sahip & Frekans & Yüzde \% \\
Öğrencilerin Eğitimi Hakkında & & \\
Eğitim Alma & & \\
\hline Hayır & 111 & 98,2 \\
Evet & 2 & 1,8 \\
Toplam & 113 & 100,0 \\
\hline
\end{tabular}

Tablo 3'de görüldüğü gibi örneklem grubunun \%98,2'si işitme yetersizliğine sahip öğrenciler hakkında eğitim almamış, \%1,8'i almıştır.

\section{Veri Toplama Araçları}

Araştırmada veri toplama aracı olarak araştırmacılar tarafından geliştirilen "Sınıfında Kaynaştırma Eğitimine Dahil Olan Işitme Yetersizliğine Sahip Öğrencilerin Dinleme Becerilerini Geliştirmeye Yönelik Öğretmen Görüşleri Ölçeği” kullanılmıştır. Buna ek olarak ölçeğe, iki açık uçlu soru eklenmiştir. Ölçme aracının geçerlik ve güvenirliği hakkında aşağıdaki başlıkta detaylara yer verilmiştir.

\section{Ölçme aracı}

Alanyazında işitme yetersizliği ve dinleme becerisine dair çeşitli araştırmalar incelenmiştir (Erdem \& Erdem, 2014; Eriks-Brophy \& Whittingham, 2013; Funk \& Funk, 1989; Rekkedal, 2015; Rost, 2011; Şahin \& Aydın, 2009). Buna bağlı olarak araştırmacılar tarafindan araştırmada kullanılacak ölçek geliştirilmiştir. Öncelikle madde havuzu oluşturma aşamasından başlanmıştır. Ön deneme ölçeği 30 maddelik 5'li likert tipi olarak hazırlanmıştır. Kapsam geçerliliği için 5 kaynaştırma eğitimine dahil olan işitme yetersizliğine sahip öğrencisi bulunan sınıf öğretmenine deneme formu uygulanmıştır. Buna ek olarak 3 alan uzmanın (işitme yetersizliği alanında öğretim üyesi, eğitim bilimleri alanında öğretim üyesi ve sınıf öğretmeni) görüşü alınmıştır. Deneme ve uzman görüşü sonucunda maddelerde anlamca düzeltme ve sadeleştirme yoluna gidilmiştir. Bunun hemen ardından ölçek maddelerinin en az beş katı kadar 
(Bryman \& Cramer, 1999) işitme yetersizliğine sahip öğrenciler ile deneyimi olan 150 sinıf öğretmenine ölçek uygulanmıştır. Uygulama sonrasında ölçeğin geçerlilik ve güvenirliği hesaplanmıştır (Balcı, 2005; Tezbaşaran, 2008)

$\mathrm{Bu}$ çalışmadaki ölçeğin yapı geçerliği öncelikle açımlayıcı faktör analizi (AFA) ile daha sonra doğrulayıcı faktör analizi (DFA) ile saptanmıştır. Faktör analizinin yapılabilmesi için Kaiser-Meyer-Olkin (KMO) değerinin minumum 0,60 ve Bartlett's testinin anlamlı çıkması gerekmektedir (Tabachnick \& Fidel, 2007). Bu çalışma için, KMO katsayısı .78 bulunmuştur. Barlett's testinde, Ki-kare değeri $1634.841(p<.001)$ olarak hesaplanmıştır. KMO katsayısı ve Bartlett's testi sonucundan elde edilen bulgular, faktör analizi yapabilmek için üzerinde çalışılan örneklem büyüklüğünün yeterli ve verilerin ise faktör analizi için uygun olduğunu göstermiştir. Buna bağlı olarak yapılan AFA'ya bağlı bulunan faktörlerin öz değeri ve açıkladıkları varyans tablo 4'te sunulmuştur.

Tablo 4. Ölçek faktörlerinin açıkladıkları öz değer ve açıklanan varyans

\begin{tabular}{ccc}
\hline Faktörler & Öz Değer & Açıklanan Varyans (\%) \\
\hline $1-$ & 4.733 & 18.154 \\
$2-$ & 1.881 & 16.885 \\
$3-$ & 1.566 & 14.352 \\
$4-$ & 1.087 & 12.386 \\
Toplam & 908 & 61.778 \\
\hline
\end{tabular}

AFA sonucunda Tablo 4'te görüldüğü gibi ölçekte özdeğeri 1'den büyük olan 4 faktör ortaya çıkmıştır. Herhangi bir faktöre dahil olmayan binişik ve faktör yükü düşük olan 15 madde analiz dışında tutulmuş ve 4 faktörlü model 15 madde üzerinden ölçek incelemesi yapılmıştır. Dört özdeğerin açıkladığı toplam varyans \% 61,778'dır. Faktörlerin açıkladıkları varyans miktarları sırasıyla birinci faktör için \%18.154; ikinci faktör için \%16.885; üçüncü faktör için \%14.352; dördüncü faktör için \%12.386'dir. Her maddenin faktör yükü değerleri ise tablo 5'te sunulmuştur.

Tablo 5. Faktör yük değerleri

\begin{tabular}{|c|c|c|c|c|c|c|c|c|}
\hline \multirow{2}{*}{$\begin{array}{l}\text { Madde } \\
\text { (M) }\end{array}$} & \multicolumn{2}{|c|}{ Faktör 1} & \multicolumn{2}{|c|}{ Faktör 2} & \multicolumn{2}{|c|}{ Faktör 3} & \multicolumn{2}{|c|}{ Faktör 4} \\
\hline & AFA & DFA & AFA & DFA & AFA & DFA & AFA & DFA \\
\hline M 17 & 7.786 & .682 & & & & & & \\
\hline M 16 & .751 & .712 & & & & & & \\
\hline M 15 & .724 & .706 & & & & & & \\
\hline M 14 & .658 & .602 & & & & & & \\
\hline M 3 & & & .790 & .428 & & & & \\
\hline M 1 & & & .776 & .497 & & & & \\
\hline M 12 & & & .681 & .590 & & & & \\
\hline M 18 & & & .652 & .737 & & & & \\
\hline M 5 & & & .499 & .747 & & & & \\
\hline M 25 & & & & & .813 & .662 & & \\
\hline M 24 & & & & & .803 & .571 & & \\
\hline M 13 & & & & & .713 & .772 & & \\
\hline M 21 & & & & & & & .786 & .632 \\
\hline M 22 & & & & & & & .704 & .700 \\
\hline M 20 & & & & & & & .590 & .838 \\
\hline
\end{tabular}




\section{İşitme Yetersizliğine Sahip Öğrencilerin Dinleme Becerilerini Geliştirmeye Yönelik Sınıf Öğretmenlerinin Görüșlerinin İncelenmesi}

Tablo 5'te ölçeğin AFA ve DFA madde faktör yükleri görülmektedir. Buna göre AFA'ya göre en en düşük madde faktör yükü M 5'e ait .499 iken, en yüksek madde faktör yükü ise M 25' ait olan .813'tür. Bunun yanı sıra DFA'da maddelerin faktör yük değerleri 0.43-0.84 arasında arasında değiştiği ve tüm yük değerlerinin istatistiksel olarak anlamlı olduğu görülmektedir $(p<.001)$.

Ölçeğin faktör yapı modeli DFA ile test edilmiştir. DFA sonucu ulaşılan uyum indeksleri tablo 6'da sunulmuştur. Tablo 6'da görüldüğü gibi, DFA sonucunda RMSEA=0.072, $\mathrm{CFI}=0.92, \mathrm{NFI}=0.83$, TLI $=0.88$ değerleri modelin uyum gösterdiğini ortaya koymuştur. RMSEA'nın \%90 güven aralığı da $(0.059 ; 0.076)$ modelin kabul edilebilir sınırlar içinde olduğunu göstermiştir. DFA ile hesaplanan Ki Kare'nin serbestlik derecesine oranı $\left(\chi^{2} / \mathrm{sd}\right)$ $129,379 / 77=1.68^{\prime}$ dir $(p=.000)$ ve bu sonuç önerilen faktör modelinin iyi uyumlu olduğunu göstermektedir.

Tablo 6. Doğrulayıcı faktör analizi için uyum indeksleri

\begin{tabular}{lcccccc}
\hline & $\mathrm{X}^{2}$ & $\mathrm{X}^{2} / \mathrm{sd}$ & RMSEA & CFI & NFI & TLI \\
\hline Dört Faktörlü Yap1 & 129,379 & 1.68 & 0.072 & 0.92 & 0.83 & 0.88 \\
\hline
\end{tabular}

Ki-kare/serbestlik derecesi 5 değerinden küçük ise modelin uyum iyiliğine sahip olduğu, 3 değerinden daha küçük ise modelin çok iyi bir uyuma sahip olduğu kabul edilir. Uyum iyiliği indeksleri için 0,90-0,95 kabul edilebilir ve 0,95 üzerinde olması ise yüksek bir uyumu gösterir (Byrne, 1998). Genel olarak bakıldığında ölçeğin DFA incelemesi sonucunda uyum indekslerinin 4 boyutlu modele uygun uyum gösterdiği sonucuna ulaşılmıştır. Güvenirlik çalışması için iç tutarlık katsayısı hesaplanmıştır. Ölçeğin tamamı için Cronbach's Alpha güvenirlik katsayısı .84 'tür. Ölçek maddelerine uygun belirlenen alt boyutlarının adları, alt boyutların altındaki maddeler ve Cronbach's Alpha güvenirlik katsayısıları tablo 7'de görülmektedir.

Tablo 7. Ölçek faktörlerinin adları ve maddeler

\begin{tabular}{clccc}
\hline $\begin{array}{l}\text { Alt } \\
\text { Ölçekler }\end{array}$ & Adı & Maddeler & $\begin{array}{c}\text { Cronbach’s Alpha Güvenirlik } \\
\text { Katsayısı }\end{array}$ \\
\hline $1-$ & Anlama & & $14,15,16,17$ & .78 \\
$2-$ & Dinleme Öncesi & ve & $1,3,5,12,18$ & .76 \\
& Sonras1 & & & \\
$3-$ & Yorumlama & & $13,24,25$ & .73 \\
$4-$ & Üst bilişsel Dinleme & $20,21,22$ & .67 \\
\hline
\end{tabular}

Tablo 7'de görüldüğü gibi ölçekte yer alan maddelerden 14, 15, 16, 17. maddeler birinci alt boyut "Anlama"; 1, 3, 5, 12, 18. maddeler ikinci alt boyut "Dinleme Öncesi ve Sonrası", 13, 24, 25. maddeler üçüncü alt boyut "Yorumlama", 20, 21, 22. maddeler dördüncü alt boyutu "Üstbilişsel Dinleme" olarak adlandırılmıştır. Cronbach's Alpha güvenirlik katsayıları birinci alt boyut (madde 14,15,16,17) için, .78; ikinci alt boyut (madde 1,3,5,12,18) için, .76; üçüncü alt boyut (madde 13, 24, 25) için, .73, dördüncü alt boyut (madde 20, 21, 22) için, .67 olarak hesaplanmıştır. Bir ölçeğe ait güvenirlik analizi için Cronbach's Alpha değerinin .70'in üzerinde olması (Büyüköztürk, 2007) iyi bir değer olarak kabul edilmektedir. Bu sonuçlar ölçeğin güvenirlik sonuçlarının yüksek olduğuna işaret etmektedir. 


\section{Verilerin Toplanması}

$\mathrm{Bu}$ araştırmanın verileri Bursa ilinde 2016-2017 eğitim öğretim yılında birinci ve ikinci yarı dönemlerinde "Sınıfında Kaynaştırma Eğitimine Dahil Olan Işitme Yetersizliğine Sahip Öğrencilerin Dinleme Becerilerini Geliştirmeye Yönelik Öğretmen Görüşleri Ölçeği" aracılığıyla toplanmıştır. Veri toplama araçlarında yer alan açık uçlu soruların yanıtları yazılı olarak alınmıştır.

\section{Verilerin Analizi}

Araştırmada elde edilen verilerin analizinde betimsel istatistikler (t-testi, tek yönlü varyans analizi, yüzde ve frekans) kullanılmıştır ve SPSS 18 programı yardımıyla yapılmıştır. Ulaşılan ve değerlendirmeye uygun bulunan tüm formlar Öğretmen 1 (Ö 1) ile başlayarak sirasiyla numaralanmıştır. Açık uçlı soruların analizinde iki araştırmacı ayrı ayrı kodlamalar yapmıştır. Sonrasında kodlamalar karşılaştırılarak tartışılmışıı ve kodlardan yola çıkarak içerik analizi yoluyla temalar belirlenmiştir. Bu araştırmada açık uçlu sorulara verilen yanıtlardan bazıları doğrudan alıntılar yapılarak ham veri yorum katılmadan okuyucuya aktarılacaktır (Yıldırım \& Şimşek, 2011). Doğrudan alıntılara yer verilirken satır (s) numaraları kullanılmıştır.

\section{Araştırmanın Geçerlik ve Güvenirliği}

$\mathrm{Bu}$ araştırmanın geçerlik ve güvenirliğini sağlamak için veri toplama ve analiz süreçleri açık ve ayrıntılı bir biçimde rapor edilmiştir. Araştırmadaki ölçme aracının geçerliği AFA ve DFA ile, güvenirliği ise Cronbach Alpha güvenirlik yöntemi ile test edilmiştir (Karasar, 2003). Ölçme aracının geçerlik ve güvenirliğine dair ayrıntılara Ölçme Aracı başlığı altında yer verilmiştir.

Açık uçlu soruların yanıtları okunarak kodlamalar yapılmıştır. Kodlardan yola çıkarak temalar ortaya konulmuş ve frekans ile yüzde değerleriyle birlikte tablo olarak sunulmuştur (Yıldırım \& Şimsek, 2011). Araştırmanın bulgular bölümünde, aktarılabilirlik ve inandırıcılığını desteklemek bakımından teyit edilebilir bir şekilde doğrudan alıntılara yer verilmiştir (Creswell, 2007). Araştırmanın güvenilirlik hesaplaması için Miles ve Huberman'ın (1994) formülü (Güvenirlik = görüş birliği / (görüş birliği + görüş ayrıllğı) x 100 kullanılarak hesaplanmıştır. $\mathrm{Bu}$ araştırmaya özgü olarak gerçekleştirilen güvenirlik çalışmasında 98 oranında bir uzlaşma (güvenirlik) sağlanmıştır.

\section{Bulgular}

1. "Sınıf öğretmenlerinin kaynaştırma eğitimine dahil olan işitme yetersizliğine sahip öğrencilerinin dinleme becerilerini geliştirmeye yönelik görüşleri öğretmenlik mesleki kıdem bakımından farklılık göstermekte midir?"alt problemine ait bulgular tablo 8'de ve tablo 9'da görülmektedir. 


\section{İşitme Yetersizliğine Sahip Öğrencilerin Dinleme Becerilerini Geliştirmeye Yönelik Sınıf}

Öğretmenlerinin Görüşlerinin İncelenmesi

Tablo 8. Ölçek faktörlerinin kıdeme göre aritmetik ortalama, standart sapma ve standart hataları

\begin{tabular}{|c|c|c|c|c|c|}
\hline & Kidem & $\mathrm{n}$ & $\overline{\bar{X}}$ & $S$ & $\mathrm{SH}$ \\
\hline \multirow{5}{*}{ 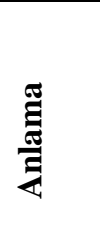 } & $1-5 \mathrm{y}_{11}$ & 7 & 16,14 & 2,34 & 88 \\
\hline & 6-10yıl & 23 & 15,96 & 2,64 &, 55 \\
\hline & $11-20 y_{11}$ & 54 & 17,74 & 1,80 &, 24 \\
\hline & 21 yıl ve üzeri & 29 & 17,28 & 1,58 &, 29 \\
\hline & Toplam & 113 & 17,16 & 2,08 & ,20 \\
\hline \multirow{5}{*}{ 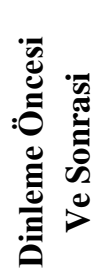 } & $1-5 y_{11}$ & 7 & 22,00 & 2,00 &, 76 \\
\hline & 6-10y1l & 23 & 20,91 & 2,97 & ,62 \\
\hline & 11-20yll & 54 & 23,15 & 5,58 &, 76 \\
\hline & 21 yıl ve üzeri & 29 & 21,10 & 2,66 & ,49 \\
\hline & Toplam & 113 & 22,1 & 4,42 &, 42 \\
\hline \multirow{5}{*}{ 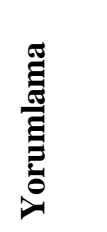 } & $1-5 y_{11}$ & 7 & 12,58 & 2,64 & ,99 \\
\hline & 6-10y1l & 23 & 12,70 & 1,52 &, 32 \\
\hline & 11-20yıl & 54 & 13,28 & 1,37 & ,19 \\
\hline & 21 y1l ve üzeri & 29 & 12,66 & 1,40 & ,26 \\
\hline & Toplam & 113 & 12,96 & 1,51 &, 14 \\
\hline \multirow{5}{*}{ 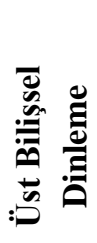 } & $1-5 y_{11}$ & 7 & 12,71 & 1,25 &, 47 \\
\hline & 6-10y1l & 23 & 12,91 & 1,93 &, 40 \\
\hline & $11-20 y_{11}$ & 54 & 13,00 & 1,44 & ,20 \\
\hline & 21 y1l ve üzeri & 29 & 12,13 & 1,83 &, 34 \\
\hline & Toplam & 113 & 12,74 & 1,66 &, 16 \\
\hline \multirow{5}{*}{ 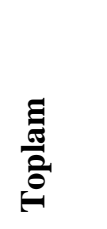 } & $1-5 y_{1} 1$ & 7 & 63,43 & 6,80 & 2,57 \\
\hline & $6-10 y_{1} 1$ & 23 & 62,48 & 7,41 & 1,54 \\
\hline & $11-20 \mathrm{y} 11$ & 54 & 67,17 & 7,26 & ,99 \\
\hline & 21 yıl ve üzeri & 29 & 63,17 & 6,53 & 1,21 \\
\hline & Toplam & 113 & 64,96 & 7,31 & ,69 \\
\hline
\end{tabular}

Tablo 8'de anlama boyutunda 11-20 yıllık k1deme sahip 54 öğretmenin aritmetik ortalaması $(\bar{X}=17,74), 21$ yıl ve üzeri kıdeme sahip 29 ögretmenin aritmetik ortalaması $(\bar{X}=17,28)$ toplam puan ortalamasının $(\bar{X}=17,16)$ üzerinde görülmektedir. Ölçeğin toplam puanları bakımından 11-20 yıllık kıdeme sahip 54 öğretmenin aritmetik ortalaması $(\bar{X}=67,17)$ toplam puan ortalamasının ( $\bar{X}=64,96)$ üzerinde görülmektedir. 
Tablo 9. Örneklem grubunun öğretmenlik deneyim yıllarına göre anova çözümlemesi sonuçları

\begin{tabular}{|c|c|c|c|c|c|c|}
\hline & & KT & $\mathrm{df}$ & $\mathrm{KO}$ & $\mathrm{F}$ & $\mathrm{p}$ \\
\hline \multirow{3}{*}{ 竘 } & Gruplar aras1 & 59,156 & 3 & 19,72 & \multirow[t]{3}{*}{5,05} & ,003* \\
\hline & Gruplar içi & 425,977 & 109 & 3,91 & & $(6-10)-(11-20) *$ \\
\hline & Toplam & 485,133 & 112 & & & \\
\hline \multirow{3}{*}{ 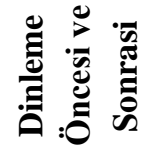 } & Gruplar aras1 & 120,599 & 3 & 40,20 & \multirow{3}{*}{2,12} & \multirow{3}{*}{,101 } \\
\hline & Gruplar içi & 2063,331 & 109 & 18,93 & & \\
\hline & Toplam & 2183,929 & 112 & & & \\
\hline \multirow{4}{*}{ 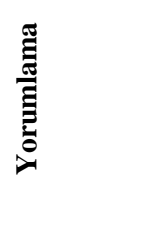 } & Gruplar aras 1 & 10,810 & 3 & 3,60 & \multirow[t]{3}{*}{1,60} & \multirow[t]{3}{*}{,194 } \\
\hline & Gruplar içi & 245,969 & 109 & 2,26 & & \\
\hline & Toplam & 256,779 & 112 & & & \\
\hline & Gruplar aras1 & 14,855 & 3 & 4,95 & \multirow[t]{3}{*}{1,83} & \multirow[t]{3}{*}{,146 } \\
\hline \multirow{2}{*}{ 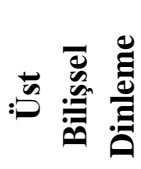 } & Gruplar içi & 294,703 & 109 & 2,70 & & \\
\hline & Toplam & 309,558 & 112 & & & \\
\hline \multirow{3}{*}{ } & Gruplar arası & 513,687 & 3 & 171,23 & \multirow[t]{3}{*}{3,41} & \multirow{3}{*}{$\begin{array}{c}, 020^{*} \\
(6-10)-(11-20)^{*}\end{array}$} \\
\hline & Gruplar içi & 5475,091 & 109 & 50,23 & & \\
\hline & Toplam & 5988,779 & 112 & & & \\
\hline
\end{tabular}

Tablo 9'da görüldüğü sınıf öğretmenlerinin işitme yetersizliğine sahip öğrencilerinin dinleme becerilerini geliştirmeye yönelik anlama boyutuna göre görüşleri, öğretmenlerin deneyim y1llarına göre anlamlı bir fark göstermektedir $\left.\left[F_{(3-109)}=5.05 ; p<0.05\right]\right)$. Anlama boyutunda 6-10 y1llık kıdeme sahip öğretmenler ile ( $\bar{X}=15,96), 11-20$ y1llık kıdeme sahip öğretmenler arasında 11-20 y1llık k1deme sahip öğretmenlerin lehine $(\bar{X}=67,17)$ anlamlı farklılık görülmektedir. Sınıf öğretmenlerinin işitme yetersizliğine sahip öğrencilerin dinleme becerilerini geliştirmeye yönelik dinleme öncesi ve sonrast, yorumlama ve üst bilişsel boyutlara göre görüşleri, öğretmenlerin deneyim yıllarına göre anlamlı bir fark göstermektedir $(p>0.05)$. Öte yandan ölçeğin toplam puanları bakımından, öğretmenlerin deneyim yıllarına göre anlamlı bir fark görülmektedir $\left.\left[F_{(3-109)}=3.41 ; p<0.05\right]\right)$. Buna göre 6-10 y1llık k1deme sahip öğretmenler ile $(\bar{X}=62,48), 11-20$ y1llık kıdeme sahip öğretmenler arasında 11-20 y1llık kıdeme sahip öğretmenlerin lehine ( $\bar{X}=63,17)$ anlamlı farklılık görülmektedir. Buna bağlı olarak 11-20 y1llık kıdeme sahip olan öğretmenlerin işitme yetersizliğine sahip öğrencilerinin dinleme ve anlama becerilerini geliştirmeye yönelik görüşlerinin daha olumlu olduğu söylenebilir.

2. "Sınıf öğretmenlerinin kaynaştırma eğitimine dahil olan işitme yetersizliğine sahip öğrencilerinin dinleme becerilerini geliştirmeye yönelik görüşleri destek eğitim sağlama bakımından farklılık göstermekte midir?"alt problemine ait bulgular tablo 10'da görülmektedir. 


\section{İşitme Yetersizliğine Sahip Öğrencilerin Dinleme Becerilerini Geliştirmeye Yönelik Sınıf}

Öğretmenlerinin Görüşlerinin İncelenmesi

Tablo 10. Örneklem grubunun destek eğitimi sağlama durumuna göre t-testi sonuçları

\begin{tabular}{|c|c|c|c|c|c|c|c|}
\hline & $\begin{array}{c}\text { Destek Eğitimi } \\
\text { Sağlama } \\
\text { Durumu }\end{array}$ & $\mathrm{n}$ & $\bar{X}$ & SS & sd & $t$ & $p$ \\
\hline \multirow[t]{2}{*}{ Anlama } & Yok & 89 & 17,31 & 1,95 & 111 & 1,53 & ,127 \\
\hline & Var & 24 & 16,58 & 2,47 & & & \\
\hline \multirow{2}{*}{$\begin{array}{l}\text { Dinleme Öncesi } \\
\text { ve Sonrasi }\end{array}$} & Yok & 89 & 22,29 & 4,74 & 111 & ,90 & ,369 \\
\hline & Var & 24 & 21,38 & 2,89 & & & \\
\hline \multirow[t]{2}{*}{ Yorumlama } & Yok & 89 & 13,00 & 1,48 & 111 &, 60 &, 552 \\
\hline & Var & 24 & 12,79 & 1,64 & & & \\
\hline Üst Bilişsel & Yok & 89 & 12,81 & 1,72 & 111 &, 81 &, 422 \\
\hline Dinleme & Var & 24 & 12,50 & 1,41 & & & \\
\hline \multirow[t]{2}{*}{ Toplam } & Yok & 89 & 65,42 & 7,27 & 111 & 1,29 & ,199 \\
\hline & Var & 24 & 63,25 & 7,37 & & & \\
\hline
\end{tabular}

Tablo 10 'da görüldüğ̈ gibi ölçeğin tüm boyutlarında ve toplam puanlarında işitme yetersizliğine sahip öğrencilerinin dinleme ve anlama becerilerini geliştirmeye yönelik sınıf öğretmenlerinin görüşleri, destek eğitimi sağlama bakımından anlamlı farklılık göstermemektedir (anlama boyutu $\left[t_{(111)}=1.53 ; p>0.05\right]$, dinleme öncesi ve sonrasi boyutu $\left[t_{(111)}=.90 ; p>0.05\right]$, yorumlama boyutu $\left[t_{(111)}=.81 ; p>0.05\right]$, üst bilişsel dinleme boyutu $\left[t_{(111)}=\right.$ $.81 ; p>0.05]$ ve toplam $\left.\left[t_{(111)}=1.29 ; p>0.05\right]\right)$.

3. "Sınıf öğretmenlerinin kaynaştırma eğitimine dahil olan işitme yetersizliğine sahip öğrencilerinin dinleme becerilerini geliştirmeye yönelik görüşleri işitme yetersizliğine sahip bireyler hakkında eğitim alma bakımından farklılık göstermekte midir?" alt problemine ait bulgularda karşılaştırma yapılacak örneklem sayısı yeterli olmadığından karşılaştırma yapılmamıştır (eğitim alan 2 kişi; eğitim almayan 111 kişi).

4. "Sınıf öğretmenlerinin kaynaştırma eğitimine dahil olan işitme yetersizliğine sahip öğrencilerinin dinleme becerilerini geliştirmeye yönelik uyguladıkları yöntemler nelerdir?” alt problemine ilişkin bulgular tablo 12'de gösterilmektedir.

Tablo 12. Örneklem grubunun işitme yetersizliğine sahip öğrencilerinin dinleme becerilerini geliştirmeye yönelik uygulamaları

\begin{tabular}{lcc}
\hline Uygulama Adları & Frekans $(f)$ & Yüzde (\%) \\
\hline Görsel Materyal Kullanma & 15 & 13,3 \\
Fiziksel Düzenleme & 15 & 13,3 \\
Derse katılımını sağlama & 4 & 3,5 \\
Konuşma hııı, tonu & 3 & 2,7 \\
Göz teması kurma & 2 & 1,8 \\
Şiir,şarkı,drama katılımı & 2 & 1,8 \\
Toplam & 41 & 36,4 \\
\hline
\end{tabular}

Tablo 12'de görüldüğü gibi, sınıf öğretmenlerinin işitme yetersizliğine sahip öğrencilerinin dinleme becerilerini geliştirmeye yönelik en fazla yaptığı uygulamaların görsel materyal kullanma $(f=15, \% 13,3)$ ve fiziksel düzenleme $(f=15, \% 13,3)$ olduğu belirlenmiştir. 
Bunu Öğretmen (Ö) 108 görsel materyal kullanmaya dair düşüncelerini “...Dinleme eğitiminde kullanılan metinlerdeki olayların resimlerle de gösterilmesi, resimler üzerinde çalışılması daha fayda sağlamaktadır." (Ö 108, s. 233-236) olarak ifade etmektedir. Ö 99 ise fiziksel düzenlemelere dair uygulamasını

"Birinci sınıftan itibaren yaka mikrofonu kullanmaktayım. Öğrencilerine yakın olarak ders anlattı̆̆ımda onların duyabildiğinin algıladım. Önce bir yaka mikrofonu edindim. Ardından bilgisayara bağlı olan hoparlörü öğrencilerimin masasina biraktım. Artık sinıfin neresinde ders anlatırsam anlatayım ögrencilerimin tıpk yanlarındaymışım gibi beni rahatllkla duyabildiklerini keşfettim. Bu onların başarılarını \%70 lere çıkarmamı sağladı.” (Ö 99, s.203208)

olarak ifade etmiştir. Ö 16 ise "İşitme engelli ögrencimi kendime yakın oturtuyorum..." (Ö 16, s.37-40) biçiminde uygulanan fiziksel düzenlemeden bahsetmektedir.

Bunları, öğrencilerin derse katılımını sağlama $(f=4, \% 3,5)$ ve öğretmenin kendi konuşma hızı ve tonu düzenlemeleri $(f=3, \% 2,7)$ uygulamaları takip etmektedir. Ö 69 "Daha fazla ilgi gösterip derse katılımını sağllyorum. Kendine güven ortamı oluşturmaya çalışıyorum..." (Ö 69, s. 151-154) ifadesi ile öğrencinin derse katılımını destekleyerek dinleme becerilerini geliştirmeye çalıştığ anlaşılmaktadır. "Ö 27 ise “...Ses tonumu öğrencinin duyabileceği ses aralı̆̆ına ayarlıyorum. Dinleme metninde özellikle o ögrenciyle göz teması kuruyorum..." (Ö 27, s. 61-64) ifadesiyle birden fazla uygulama yaptığı anlaşılmıştır.

En az yapılan uygulamalar ise göz teması $(f=2, \% 1,8)$ ve şiir, şarkı, dramaya katılımlarını sağlama $(f=2, \% 1,8)$ 'dir. Ö 28 “...Dinleme sırasında işitme engelli ögrenci ile daha fazla göz teması kuruyorum...” (Ö 28, s.65-69) şeklinde ifade ederken Ö 45 ise öğrencisinin etkinliklere katılımını “...Ben sadece sosyalleşmesini sağladım. Şiir, şarkl, drama gibi etkinliklere katıldı..." (Ö 45, s. 121-124) olarak ifade etmektedir.

Bunların yanı sıra araştırmada sınıf öğretmenlerinin işitme yetersizliğine sahip öğrencilerinin dinleme becerilerini geliştirmeye yönelik dudak okumayı sağlama ( $f=11, \%$ 9,8 ) ve yüksek sesle öğretim yapma $(f=9, \% 7,9)$ gibi yöntemler uyguladıkları belirlenmiştir. Buna ilişkin ifadeler Ö 26 tarafından, öğrencisinin dudak okumasını sağlamayı "...Sınıf içinde öğrencinin dudak okuyarak anlamasını sağlayacak bir ortam oluşturuyorum.” (Ö 26, s. 57-60) şeklindedir. Öte yandan diğer yüksek sesle öğretim yapılarak uygun olmayan uygulamayı Ö 31 "İsitme engelli ögrrencim olduğu için bu sene çok daha fazla yüksek sesle ders anlattım. Sürekli bağırarak konuşmak gerekiyor...” (Ö 31, s. 80-84) olarak ifade etmektedir.

Bunlara ek olarak araştırmaya katılan bazı öğretmenler ( $\mathrm{f}=6, \% 5,3$ ) uygulanacak yöntemler hakkında bilgi sahibi olmadıklarını açıkça ifade etmişlerdir. Bunu Ö 33 "Farklı bir yöntem uygulayamıyorum. Çünkü bu konuda eğitim almadım." (Ö 33, s.92-93) olarak ifade ederken Ö 24 ise “Açıkçası nasıl bir yöntem uygulayacağımı bilmiyorum." (Ö 24, s.54) şeklinde açıklamıştır.

Araştırmaya katılan 113 öğretmenin 37 (\%32,7)'si işitme yetersizliğine sahip öğrencinin dinleme becerisini geliştirmeye yönelik yapılan uygulamalara dair soruya hiç yanıt vermezken, $9(\% 7,9)$ 'u da “Uygulamadım” yanıtını vermişlerdir. 


\section{İşitme Yetersizliğine Sahip Öğrencilerin Dinleme Becerilerini Geliştirmeye Yönelik Sınıf Öğretmenlerinin Görüșlerinin İncelenmesi}

5."Sınıf öğretmenlerinin kaynaştırma eğitimine dahil olan işitme yetersizliğine sahip öğrencilerinin dinleme becerilerini geliştirmeye yönelik hangi konuda yardıma ihtiyaç duymaktadırlar?" alt problemine dair bulgular aşağıda tablo 13 'te sunulmuştur.

Tablo 13. Örneklem grubunun işitme yetersziliğine sahip öğrencilerinin dinleme becerilerini geliştirmeye yönelik yardıma ihtiyaç duyduğu alanlar

\begin{tabular}{lcc}
\hline İhtiyaç duyulan alan & Frekans $(f)$ & Yüzde (\%) \\
\hline İletişim & 20 & 17,7 \\
Destek Eğitim & 10 & 8,8 \\
Cihaz kullanımı & 9 & 7,9 \\
Aile desteği & 7 & 6,2 \\
İstenmeyen davranış & 7 & 6,2 \\
Yazma & 6 & 5,3 \\
Görsel-İşitsel materyal & 6 & 5,3 \\
Okuma & 5 & 4,4 \\
Akustik düzenleme & 1 & 0,9 \\
Dikkati çekme & 1 & 0,9 \\
Öğretim yöntemleri & 1 & 0,9 \\
Toplam & 73 & 64,5 \\
\hline
\end{tabular}

Tablo 13'te görüldüğ̈̈ gibi sınıf öğretmenlerinin en çok yardıma ihtiyaç duyduğu alan iletişimdir $(f=20, \% 17,7)$. Bunu destek eğitim $(f=10, \% 8,8)$ ve cihaz kullanımı $(f=9, \% 7,9)$ takip etmektedir. Ö 101 “...Duymadığı için iletişim kurmak zor oluyor.” (Ö 101, s.543-546) en açık biçimde ifade etmiştir. Ö 113 ise "...Destek eğitimi almasını istiyorum. Aile ise çok agresif davranıyor. Aile ile iletişim normal düzeye geldiğinde çok daha iyi olacağını umuyorum." (Ö 113, s.584-588) ifadesiyle hem öğrencinin destek eğitim almasını hem de ailenin desteklenmesi gerektiğini belirtmektedir. Cihaz kullanımı konusunda kendilerini yetersiz bulduğu Ö 25 şöyle ifade etmektedir: "...Işsitme cihazı konusunda yeterli bilgim olmadığ için cihazı takma ve ayarlama konusunda zorlaniyorum...” (Ö 25, s.321-325).

Öğretmelerin ihtiyaç duydukları diğer alanlar ise aile desteği $(f=7, \% 6,2)$ ve istenmeyen davranış $(f=7, \%$ 6,2 )'tır. Ö 98 aile desteğine duyduğunu "İşitmemesinden kaynaklanan konuşma problem olduğu için bazen iletişim sorunu yaşadığımı hissediyorum. Bu konuda ailesinin desteğine ihtiyaç duyuyorum." (Ö 98, s.534-539) olarak ifade etmektedir. Ö 46 ise istenmeyen davranışlarla baş etme konusunda yardıma ihtiyaç duyduğunu "Bu tip öğrenciler genelde şiddete meyilli oluyorlar. Sağhlkl iletişim kuramadıklarından doğal olarak hırçınlaşıyorlar. Bunlarla baş etmede yardıma ihtiyaç duyuyorum" (Ö 46, 381-384) olarak ifade etmektedir.

Bunlara ek olarak öğretmenlerin yardıma ihtiyaç duyulan diğer alanlar ise yazmanın öğretimi $(f=6, \% 5,3)$, görsel-işitsel materyal yetersizliği $(f=6, \% 5,3)$ ve okuma öğretimi $(f=5$, $\% 4,4$ ) olduğu belirlenmiştir. Ö13 yazma öğretiminde yaşadığı sorunu "Yazılı anlatımda, iyelik

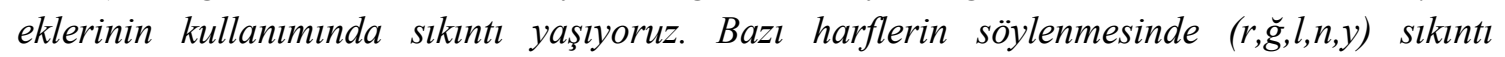
yaşıyoruz..." (Ö 13, s. 289-293) biçiminde ifade etmiştir. Görsel-işitsel materyal eksikliği konusunda yardıma ihtiyaç duyduklarını Ö 83 "İsitme yetersizliği olan ögrrencilere özgü görsel ögelerle desteklenmiş yardımcı kaynağa ihtiyaç duyuyorum" (Ö 83, s.453-455) şeklinde ifade etmektedir. 
En az akustik düzenleme $(f=1, \% 0,9)$ ve öğrencilerin derse dikkatini çekme $(f=1, \% 0,9$ ) konusunda yardıma ihtiyaç duyulduğu belirlenmiştir. Bunu Ö 5 “...Akustik sınıf ve mevcutların az olduğu sinıflara ihtiyaç duyuyorum." (Ö 5, s.263-267) olarak ifade etmiştir. Ö 24 öğrencinin derse katılımını sağlamada yaşadığı güçlüğü "Sınıfta dikkatini toplama, derse odaklanma ve derse katılımı konusunda yardıma ihtiyaç duyuyorum" (Ö 24, s.317-320) olarak ifade etmektedir. Bir öğretmen $(\% 0,9)$ işitme yetersizliğine sahip öğrencilerin eğitiminde kullanılan öğretim yöntemleri bilmediğini şöyle ifade etmiştir: “...̈̈ğrencime nasıl eğitim vermem gerektiği konusunda eğitime ihtiyaç duyuyorum" (Ö 33, s.341-344)".

Öte yandan $7(\% \quad 6,2)$ öğretmen herhangi bir sorun yaşamadığını ifade ederken, 33 $(\% 29,3)$ öğretmen bu soruya hiç yanıt vermemiştir.

\section{Tartışma}

$\mathrm{Bu}$ araştırmada sınıf öğretmenlerinin kaynaştırma eğitimine dahil olan işitme yetersizliğine sahip öğrencilerinin dinleme becerilerini geliştirmeye yönelik görüşleri çeşitli değişkenler bakımından incelenmiştir. Bu araştırmada işitme yetersizliğine sahip öğrencilerinin dinleme becerilerini geliştirmeye yönelik 11-20 yıllık kıdeme sahip sınıf öğretmenlerinin lehine anlamlı farklılık olduğu belirlenmiştir. Buna göre deneyimli öğretmenlerin geçmiş deneyimleri 1şığında işitme yetersizliğine sahip öğrencilerin dinleme becerilerini geliştirmeye yönelik olumlu görüş bildirdiği söylenebilir.

İşitme yetersizliği olan çocuklar için kaynaştırma eğitiminin başarısında, sadece sınıf öğretmenlerinin kaynaştırma eğitimine yönelik olumlu bir yaklaşım sergilemeleri değil, aynı zamanda işitme kaybının dil gelişimine, ders içi katılıma ve akademik başarıya etkisiyle ilgili temel bilgileri edinmelerini de gerektirir (Eriks-Brohpy \& Whittingham, 2013; Rhoades, 2011). $\mathrm{Bu}$ çalışmada öğretmenlerin çoğunluğunun kendi öğrencilerine destek eğitim sağlamadıkları ve işitme yetersizliğine sahip öğrencilerin eğitimine dair yeterli eğitim almadıkları belirlenmiştir. Gürgür, Kış \& Akçamete (2012)'nin çalışmasında öğretmen adayları tarafından destek hizmetlerin gerekliliğine ve sınıf öğretmenlerinin özel eğitim ve özel gereksinimli çocuklar konusunda mesleki gelişimlerine yönelik beklentileri ifade edilmiştir.

Sınıf öğretmenlerinin yarısından azı işitme yetersizliğine sahip öğrencilerinin dinleme becerilerini geliştirmeye yönelik görsel materyal kullanma, yaka mikrofonu kullanma ve sınıf içi oturma düzenine özen gösterme gibi fiziksel düzenlemelerin yanı sıra derse katılımını sağlama, kendi konuşma hızını ve ses tonunu öğrencinin duyabileceği biçimde ayarlama, göz teması kurma, şiir, şarkı ve drama gibi etkinliklere katılımını destekleme gibi düzenlemeler yaptıklarını söylemektedirler. İşitme yetersizliğine sahip öğrencilerin eğitim sürecinde sınıf oturma düzeninde yeri, telsiz FM sistemlerinin kullanılması, görsel ipucu verilmesi, göz temasının kurulması, öğretmenlerin konuşma hızlarını ve tonlarını ayarlamaları gibi etkili uygulamaların yürütülmesinde etkili bazı faktörlerin göz önünde bulundurulması gerekir (Girgin, 2006; Heward, 2013; Stith \& Drasgow, 2005; Turnbull, Turnbull, Wehmeyer \& Shogren, 2013; Tüfekçioğlu, 1992). Ancak diğer öğretmenler ya dudak okumayı sağlama ve bağırarak öğretim yapma gibi dinleme becerisinin gelişimini olumsuz etkileyecek uygulamalar (Akçakaya \& Tavşancıl, 2016; Allen, 2015; Estabrooks, 2006) yaptıklarını ya da uygulanacak yöntemleri bilmediklerini, herhangi farklı bir uygulama yapmadıklarını ifade etmişlerdir. Araştırmaya katılan öğretmenlerin üçte biri ise bu soruya hiç yanıt vermemişlerdir. Bu da sınıf öğretmenlerinin işitme yetersizliğine sahip öğrencilerin dinleme becerilerinin gelişiminde yeterli destek alamadıklarını göstermektedir. Öğretmenlerin dinleme becerisinin geliştirilmesi için 


\section{İşitme Yetersizliğine Sahip Öğrencilerin Dinleme Becerilerini Geliştirmeye Yönelik Sınıf Öğretmenlerinin Görüşlerinin İncelenmesi}

uygun yöntem ve teknikleri bilmesinin; sınıf seviyesi ile şartlarına uygun yöntem ve teknikleri kullanmasının önemi büyüktür (Funk \& Funk, 1989; Koç, 2003). Çünkü sözlü dil gelişiminin sağlanabilmesi için doğuştan işitme yetersizliği olan çocuklara dinlemenin öğretilmesi gerekmektedir (Easterbrooks \& Estes, 2007).

Sınıf öğretmenlerin büyük bir çoğunluğu dinleme becerilerini geliştirebilmek için iletişim alanında yardıma ihtiyaç duymaktadırlar. Yapılan araştırmalarda işitme yetersizliğine sahip bireylerin, doğru ve zamanında tanılanmasının, sağaltımı ve eğitiminin yapılmasının; konuşmayı algılamada, konuşma anlaş1lırlığında ve dil gelişiminde olumlu etkileri olduğu anlaşılmıştır (Hess, Zettler-Greeley, Godar, Ellis-Weismer, \& Litovsky, 2014). İşitme yetersizliğine sahip bireylerin konuşmasına alışkın olmayan sınıf öğretmenlerinin sözlü iletişim sürecinde (konuşma) onları anlayamamaları gayet doğaldır. Bunun yanı sıra kaynaştırma uygulamalarına dahil olan işitme yetersizliğine sahip öğrencinin devam ettiği genel eğitim sınıflarının gerek fiziki gerekse teknolojik ortamlarının işitme yetersizliğine sahip öğrencinin ihtiyaçlarına yönelik düzenlenmemiş olması işitme yetersizliğine sahip öğrencilerinin de öğretmenlerinin söylediklerini işitme ve algılamada zorluk çekmelerine neden olmaktadır. Öğrenme hedeflerine ve başarıya ulaşmada, öğrencilerin dinleme becerilerinin ve öğrenme ortamının özellikleri göz ardı edilemez (Robinshaw, 2007; Turan, 2007). Öğrencilerin devam etmiş oldukları sınıflamalarda akustik ve teknolojik (işitme cihazları, akustik yalıtım, FM sistemleri, açık hava yalıtım sistemleri) uygulamaların işitme yetersizliğine sahip öğrencilerin dinleme becerilerini geliştirmeye yarar sağlayacağı düşünülmektedir (Anderson, Goldstein, Colodzin \& Inglehart, 2005; Thibodeau, 2010). Öğrencinin işitmesine yardımc1 sistemler ve akustik düzenlemelerin öğrencilerin dinleme becerilerinin gelişiminde etkili faktörler olduğuna dair benzer bulgulara Rekkedal'ın (2015) çalışmasında da rastlanmaktadır. Dinleme cihazları çoğu işitme yetersizliğine sahip çocuğunun eğitsel başarısının anahtarıdır. Bir işitme cihazı, FM sistemi veya koklear implant doğru çalışmıyorsa, çocuk etkili bir şekilde öğrenemez. İşitme sistemleri çalışmadan yapılan öğretim çocuğun gözlerini kapatmasını ve bu şekilde okumasını istemek gibi bir durum olurdu. Dinleme teknolojisi sadece günlük yaşamında yardımcı değildir; bunun yanında her zaman en üst düzeyde çalışması gereken önemli bir öğretim unsurunu oluşturmaktadır. Etkili öğretmenler, teknoloji sorunlarını nasıl gidereceğini ve bu konuda kimlerden yardım alacağını bilmelidir (Easterbrooks \& Beal-Alvarez, 2013).

Gerek işitme yetersizliğine sahip gerekse normal gelişim gösteren öğrencilerin akademik ve sosyal becerilerinin gelişiminde aile desteği yadsınamaz (Calderon, 2000; Powers, 2003; Rekkedal, 2015). Araştırma bulgularında görüldügü üzere öğretmenler, öğrencilerinin başarısı için aile desteğine ihtiyaç duyduklarını ifade etmişlerdir. Gürgür, Kış \& Akçamete (2012)'nin çalışmasında da aileler ile iletişim ve işbirliği konusunda sorun yaşanıldığına dair bu araştırmaya benzer bulgulara rastlanmaktadır. Öğretmenlerin ve ailelerin özel gereksinimli öğrencilerin eğitimini işbirliği içinde yürütmeleri başarı üzerinde çok önemli etkendir (EriksBrophy \& Whittingham, 2013; Gárate \& Lenihan, 2016; Mastropieri \& Scruggs, 2014; Salend, 2005).

Tüfekçioğlu (2003), işitme yetersizliği olan bireylerin sosyal etkileşimlerde ya engellenme ve kızgınlık duyguları yaşadıkları ya da çekingen olma gibi problemler yaşadıklarını belirtmiştir. Araştırmaya katılan öğretmenlerin belirttiği üzere, işitme yetersizliğine sahip öğrencilerinin yeterli iletişim becerilerine sahip olmadıklarından çevreleri 
ile olumlu iletişim kurmaları zorlașmaktadır. Buna bağlı olarak işitme yetersizliğine sahip öğrencileri istenmeyen davranış (agresif, hırçın vb.) sergilemektedirler. Benzer olarak İpek Timur (2016) araştırmasında iletişimsel sorunlara bağlı olarak olumsuz durumlar ile karşı karşıya kalan işitme kayıplı bireylerin saldırganlık eğilimlerinin arttığı sonucuna varmıştır. İletişim becerileri geliştikçe bu davranışlarda da azalma olacağ 1 düşünülmektedir.

Etkili öğrenme süreci üzerinde materyal en etkili faktördür. Öğrenme öğretme sürecinin başlangıcından sonucuna kadar öğrencilerin ilgisini ve dikkatini etkin tutmada materyalin etkisi yadsinamaz (Heward, 22013; Rose \& Meyer, 2006; Turnbull, Turnbull, Wehmeyer \& Shogren, 2013). Bu araştırmadaki öğretmenlerin materyal ihtiyac1 olduğuna dair bulgunun benzeri bulgulara Sivrikaya \& Yıkmış (2016) ile Eldeniz Çetin \& Şen (2017)'nin araştırmalarında da rastlanmıştır. Öğretmenler, işitme yetersizliğine sahip öğrencilerine katkı sağlayabilmeleri için kendi materyallerini geliştirmeyi kendilerine amaç edinebilirler.

Öğretmenlerin bir kısmı işitme yetersizliğine sahip öğrencilerin okuma ve yazma öğretiminde sorunlar ile karşılaş̧ıklarını belirtmektedirler. Öğretmenler öğrencilere okuma ve yazmayı, dinleme ve konuşma yoluyla öğretirler (Palmer, 2014). Ancak gerekli desteği ve eğitimi almayan dil öncesi işitme kaybına sahip çocukların dil gelişimleri yaşıtlarına göre daha yavaş gelişeceğinden dolayı ana dillerinde yetersizlikler ortaya çıkabilecektir. Doğan (2007)'a göre, dinleme becerisi gelişmiş bir öğrencinin, Türkçe dersinden Matematik dersine tüm dersleri daha iyi anlamasına bağlı olarak genel başarısı yükselecektir. Sosyal yaşamında dinleme-anlama eksikliğinden kaynaklanan iletişim sorunlarıyla karşılaşmadan daha sağlıklı ilişkiler kurma firsatı bulabileceklerdir.

Elde edilen araştırma sonuçları doğrultusunda;

1) $\mathrm{Bu}$ araştırmadaki sonuçlara bağlı olarak sınıf öğretmenlerinin işitme yetersizliğine sahip öğrencilerinin eğitimine dair birçok konuda yardıma ihtiyaç duydukları anlaşılmıştır. Bu nedenle öğretmenlere, işitme yetersizliğine sahip öğrencilerinin dinleme gelişiminin yanı sıra bu öğrencilerin genel eğitimi, iletişim kurma, okuma-yazma gibi diğer akademik becerilerinin gelişimi, materyal hazırlama, öğretim yöntemleri, cihaz kullanımı, akustik düzenlemeler, istenmeyen davranış ile baş etme, aile ile işbirliği gibi konularda hizmetiçi eğitim, seminer gibi çalışmalar yoluyla gerekli eğitimi almaları önerilir.

2) Kaynaştırma eğitimine dahil olan işitme yetersizliğine sahip öğrencilerin, öğretmenlerin, diğer okul çalışanları ve ailelerinin sorunlarıyla ilgili ya da sorunların çözümü hakkındaki önerilerine ilişkin ve sorunlara müdahale çalışmalarını konu alan nitel, nicel, karma vb. araştırma yöntemleri ile yürütülen daha fazla çalışmanın yapılması önerilir. 


\section{İşitme Yetersizliğine Sahip Öğrencilerin Dinleme Becerilerini Geliştirmeye Yönelik Sınıf Öğretmenlerinin Görüșlerinin İncelenmesi}

\section{Kaynakça}

Ainscow, M. (2005). Developing inclusive education systems: What are the levers for change? Journal of Educational Change, 6(2), 109-124. https://doi.org/10.1007/s10833-005-1298-4

Akçakaya, H. \& Tavşancıl, E. (2016). Teacher opinions about auditory verbal therapy. Eğitimde Nitel Araştırmalar Dergisi- Journal of Qualitative Research in Education, 4(2), 7-28. [Online]: http://www.enadonline.com http://dx.doi.org/10.14689/issn.2148-2624.1.4c2s1m

Allen, T. (2015). The deaf community as a 'special linguistic demographic': Diversity rather than disability as a framework for conducting research with individuals who are deaf. E. Orfanidou, B. Woll, \& G. Moran (Eds.), The Blackwell guide to research methods in sign language studies. Hoboken, NJ: John Wiley.

Anderson, K., Goldstein, H., Colodzin, L., \& Inglehart, F. (2005). Benefit of S/N enhancing devices to speech perception of children listening in a typical classroom with hearing aids or a cochlear implant. Journal of Educational Audiology, 12, 14-28.

Avramidis, E., \& Norwich, B. (2002). Teachers' attitudes towards integration/inclusion: A review of the literature. European Journal of Special Needs Education, 17(2), 129-147. https://doi.org/10.1080/08856250210129056.

Balc1, A. (2005). Sosyal bilimlerde araştırma. Ankara:Pegem A yayınc1lık.

Bryman, A., \& Cramer, D. (1999). Quantitative data analysis with spss release 8 for windows. a guide for social scientists. London: Routledge.

Büyüköztürk, Ş. (2007). Sosyal bilimler için veri analizi el kitabl. İstatistik, araştırma deseni SPSS uygulamaları ve yorum. (7. Baskı). Ankara: Pegem A Yayıncılık.

Byrne, B. M. (1998). Structural equation modeling with lisrel, prelis and simlis: Basic concepts, aplications andprogramming. Mahwah, NJ: Lawrence Erlbaum Associates.

Calderon, R. (2000). Parental involvement in deaf children's education programs as a predictor of child's language, early reading, and social-emotional development. Journal of Deaf Studies and Deaf Education, 5(2), 140- 155. http://dx.doi.org/10.1093/deafed/5.2.140

Chafe, W. (2000) Loci of diversity and convergence in thought and language, M. Pütz \& M. Verspoor (Ed) Explorations in linguistic relativity (101-23), Amsterdam: Benjamins.

Ciğerci, F. M. (2015). İlkokul dördüncü sinıf Türkçe dersinde dinleme becerilerinin gelişstirilmesinde dijital hikayelerin kullanılması. Yayımlanmamış doktora tezi, Anadolu Üniversitesi, Eğitim Bilimleri Enstitüsü, Eskişehir.

Cochlear Limited (2005). Listen learn and talk: Another cochlear innovation. Australia: Cochlear Limited.https://www.cochlear.com/in/home/support/rehabilitation-resources/earlyintervention/listen-learn-and-talk sitesinden 05.08.2018 tarihinde alınmıştır.

Cole, E., \& Flexer, C. (2007). Children with hearing loss: Developing listening and talking, birth to six. San Diego: Plural Publishing.

Crandell, C., \& Smaldino, J. (2000). Room Acoustics and Amplification. Valente, M., Roeser, R., \& Hosford-Dunn, H. (Ed.), Audiology: Treatment Strategies, New York: Thieme.

Creswell, J. W. (2007). Qualitative inquiry and research design: Choosing among five approaches (2nd ed.). Thousand Oaks, CA, US: Sage Publications, Inc.

Dockrell, J.E., \& Shield, B.M. (2006). Acoustical barriers in classrooms: The impact of noise on performance in the classroom. British Educational Research Journal, 32(3), 509-525. https://doi.org/10.1080/01411920600635494

Doğan, Y. (2007). İlköğretim ikinci kademe dil becerisi olarak dinlemeyi geliştirme çalışmaları. Yayımlanmamış doktora tezi, Gazi Üniversitesi, Eğitim Bilimleri Enstitüsü, Ankara.

Doğan, Y., \& Özçakmak, H. (2014). Dinleme becerisinin eğitimi üzerine yapılan lisansüstü tezlerin değerlendirilmesi. Ana Dili Ĕ̈itimi Dergisi, 2(2), 90-99.

Durmuş, N. (2013). İlköğretim 2. sinıf öğrencilerinin dinleme becerilerinin geliş̧tirilmesinde çocuk edebiyatı ürünlerinin etkisi. Yayınlanmamış yüksek lisans tezi, Uludağ Üniversitesi, Eğitim Bilimleri Enstitüsü, Bursa.

Estabrooks, W. (2006). Auditory-verbal therapy and practice. Washington, DC: A. G. Bell.

Easterbrooks, S. R., \& Beal-Alvarez, J. (2013). Literacy instruction for students who are deaf and hard of hearing. New York, NY: Oxford University Press.

Easterbrooks, S.R., \& Estes, E. (2007). Helping deaf and hard of hearing children to usespoken language. Thousand Oaks: Corwin Press. 
Eldeniz Çetin, M.,ve Şen, G.S. (2017). Özel eğitim ve rehabilitasyon merkezlerinde çalışan ögretmenlerin sorunlarının belirlenmesi. International Journal of Social Science, 59, 53-65.

Erdem, A., \& Erdem, M. (2014). "DinleİzleAnlat” dinleme ve konuşma yeterlikleri ölçeğinin geliştirilmesi. Ĕ̌itim ve Öğretim Araştırmaları Dergisi, 3(4), 418-432.

Eriks-Brophy, A., \& Whittingham, J. (2013). Teachers' perceptions of the inclusion of children with hearing loss in general education settings. American Annals of the Deaf, 158(1), 63-97.

Funk, H., \& Funk, G.D. (1989). Guidelines for developing listening skills. The Reading Teacher, 42, 66063.

Gárate, M., \& Lenihan, S. (2016). Collaboration for communication, language, and cognitive development. In M. Sass-Lehrer (Ed.), Early intervention for deaf and hard of hearing infants, toddlers, and their families. New York: Oxford University Press.

Geers, A. E., Moog, J. S., Biedenstein, J., Brenner, C., \& Hayes, H. (2009). Spoken language scores of children using cochlear implants compared to hearing age-mates at school entry. Journal of Deaf Studies and Deaf Education, 14, 371-385. doi:10.1093/deafed/enn046

Girgin, C. (2006). İșitme engelli çocukların konuşma edinimi eğitiminde dinleme becerilerinin önemi. Ankara Üniversitesi Ĕgitim Bilimleri Fakültesi Özel Ĕ̈itim Dergisi, 7(1), 15-28.

Gürgür, H., K1ş, A. \& Akçamete, G. (2012). Kaynaştırma öğrencilerine sunulan bireysel destek hizmetlere ilişkin öğretmen adaylarının görüşlerinin incelenmesi, İlkögretim Online, 11(3), 689701.

Hess, C., Zettler-Greeley, C., Godar, S. P., Ellis-Weismer, S., \& Litovsky, R. Y. (2014). The effect of differential listening experience on the development of expressive and receptive language in children with bilateral cochlear implants. Ear and Hear, 35(4), 387-395.

Heward, W. L. (2013). Exceptional children: An introduction to special education. Ohio: Merrill Prentice Hall.

İpek Timur, A. (2016), Iş̧itme Engelli Bireylerde Dil Kullanımı ile Depresyon Arasındaki İlişkide Saldırganlık Eğiliminin Etkisi: Bir Yapısal Eşitlik Modellemesi Çalışması, Yayınlanmamış yüksek lisans tezi, İstanbul Arel Üniversitesi Sosyal Bilimler Enstitüsü Klinik Psikoloji Yüksek Lisans Programı, İstanbul.

Karasar, N. (2003). Bilimsel araştırma yöntemi. Ankara: Nobel Yayın Dağıtım.

Knecht, H., Nelson, P., \& Whitelaw, G. (2002). Background noise levels and reverberation times in unoccupied classrooms: Predictions and measurements. American Journal of Audiology, 11, 6571.

Koç, N. (2003). Dinleme becerilerini kazandırma yöntemlerinin uygulanması. Yayımlanmamış yüksek lisans tezi, Çanakkale Onsekiz Mart Üniversitesi, Sosyal Bilimler Enstitüsü, Çanakkale.

Lindsay, G. (2007). Educational psychology and the effectiveness of inclusive education / mainstreaming. British Journal of Educational Psychology, 77,1-24.

Luckner, J. L., \& Muir, S. (2001). Successful students who are deaf in general education settings. American Annals of the Deaf, 146, 450-461.

Mastropieri, M. A., \& Scruggs, T. E. (2014). The inclusive classroom: Strategies for effective differentiated instruction (5th ed.). Upper Saddle River, NJ: Pearson Education.

Palmer, E. (2014). Teaching the core skills of listening and speaking. Alexandria, VA: ASCD.

Powers, S. 2003. Influences of student and family factors on academic outcomes of mainstream secondary school deaf students. Journal of Deaf Studies and Deaf Education, 8, 57-78.

Rekkedal, A.M. (2015). Students with hearing loss and their teachers' view on factors associated with the students' listening perception of classroom communication. Deafness \& Education International. 17(1), 19-32.

Rhoades, E. A. (2011). Listening strategies to facilitate spoken language learning among signing children with cochlear implants. In R. Paludneviciene and I. W. Leigh [Eds.]. Cochlear implants: Shifting perspectives (pp. 142-171). Washington DC: Gallaudet University Press.

Robinshaw, H., (2007) Acquisition of hearing, listening and speech skills by and during key stage 1 , Early Child Development and Care, 177(6-7), 661-678.

Rose, D.H., \& Meyer, A., (Eds.) (2006). A practical reader in universal design for learning. Cambridge, MA: Harvard Education Press.

Rost, M. (2011). Teaching and researcing listening model. Harlow, UK: Pearson.

Salend, S. J. (2005). Creating inclusive classrooms: effective and reflective practices for all students (5th ed.). Upper Saddle River, New Jersey: Pearson. 


\section{İşitme Yetersizliğine Sahip Öğrencilerin Dinleme Becerilerini Geliştirmeye Yönelik Sınıf Öğretmenlerinin Görüșlerinin İncelenmesi}

Siebein, G. W., Gold, M. A., Siebein, G. W. \& Ermann, M. G. (2000). Ten ways to provide ahigh-quality acoustical environment in schools, Language, Speech, and Hearing Services in Schools, 31, 376384.

Sivrikaya, T. \& Yıkmış, A. (2016). Özel eğitim sınıflarında görev yapan özel eğitim bölümü mezunu olan ve olmayan ögretmenlerin öğretim süreci ile ilgili gereksinimleri, Abant İzzet Baysal Üniversitesi Ĕ̈itim Fakültesi Dergisi, 16(6,) 1984-2001.

Stith, J. L., \& Drasgow, E. (2005). Including children with cochlear implants in general education elementary classrooms. TEACHING Exceptional Children Plus. 2(1):22-31.

Şahin, A., \& Aydın, G. (2009). İlköğretim 6. sınıf öğrencilerinin türkçe dersi dinleme becerisi farkındalıklarının belirlenmesine yönelik bir anket geliştirme. The Journal of International Social Research,2 (9), 454- 464.

Tabachnick, B. G., \& Fidell, L. S. (2007). Using multivariate statistics, (5th ed.) Boston, MA: Allyn and Bacon.

Tezbaşaran, A.A (2008). Likert tipi ölçek hazırlama kılavuzu. (üçüncü sürüm e-kitap), http://www.academia.edu/1288035/Likert_Tipi_Olcek_Hazirlama_Kilavuzu.pdf.

Thibodeau, L. (2010). Benefits of adaptive FM systems on speech recognition in noise for listeners who use hearing aids. American Journal of Audiology, 19, 36-45. Turan , Z. (2007). Setting of classroom environments for hearing impaired children. Paper presented at the International Educational Technology (IETC) Conference (7th, Nicosia, Turkish Republic of Northern Cyprus, May 3-5.

Tüfekçioğlu U. (1992). Kaynaştırmadaki işitme engelli çocuklar. Eskişehir: Anadolu Üniversitesi Yayınları.

Tüfekçioğlu, U. (2003). İsittme, konuşma ve görme sorunları olan çocukların eğitimi. Eskişehir: Anadolu Üniversitesi Yayınları. 


\section{Introduction}

\section{Extended Abstract}

In recent years, arrangement of physical environment settings and curricula in accordance with the needs of special needs students so as to place these students in education with their peers has been a widely acknowledged inclusion practice. On the other hand, this inclusion of students with hearing impaired places a variety of additional responsibilities on classroom teachers. Based on the needs of students with hearing impaired, classroom teachers are expected to design syllabuses, organize learning-teaching activities, make physical arrangements, provide opportunities for learning and development, and support these students' development of positive communication with their peers. As the most basic element of the communication process, listening is also a prerequisite for success in individual and social relations. Development of listening skills plays an important role in raising individuals with empathy, problem-solving skills, self-confidence and an improved sense of self-perception. In the light of these points, the aim of this study was to determine primary school teachers' opinions on improving listening skills of students with hearing impaired who are included in their classrooms through inclusion education. There is currently limited research on this subject. This study could contribute to the research on primary school teachers' opinions about improving listening skills of students with hearing impaired who are included in their classrooms through inclusion education. The principal research question addressed in this study was "What are the opinions of classroom teachers about improving listening skills of students with hearing impaired who are included in their classrooms through inclusion education?".

\section{Methodology}

This study used a survey model to explore the opinions of classroom teachers in the city of Bursa about improving listening skills of students with hearing impaired who are included in their classrooms through inclusion education vary in terms of certain factors. The study population consisted of 113 primary school classroom teachers who taught students with hearing impaired through inclusion education in Bursa, Turkey. Data were collected using "The Teacher Opinion Scale for Developing Listening Skills of Students with Hearing Impaired" developed by the researchers. The pilot version of the scale was prepared as a 5-point Likert type with 30 items. The construct validity of the scale was determined by a exploratory factor analysis (EFA) followed by a confirmatory factor analysis (CFA). In addition, two open-ended questions were added to the scale, as recommended by three experts unanimously. Data were analyzed using descriptive statistics (e.g. t-test, one way analysis of variance, percentage and frequency). Those forms that were returned and found appropriate for analysis were numbered beginning from Teacher 1 (T1). Descriptive statistics were performed using SPSS version 18. For the analysis of the open-ended questions, the two researchers coded the initial data independently. After that, they discussed their agreement on coding and determined the themes through content analysis that could be reached based on coding.

\section{Findings}

In terms of duration of professional seniority, the teachers' opinions about improving the listening skills of their students with hearing impaired differed significantly in favor of those teachers with 11-20 years of seniority between teachers with 6-10 years of seniority and 11-20 years of seniority. In terms of providing support education, on the other hand, the scores for the sub-scales or the overall scale did not show any significance. There was a significant difference on only the fourth sub-scale in favor of those teachers who did not receive any training on 


\section{İşitme Yetersizliğine Sahip Öğrencilerin Dinleme Becerilerini Geliştirmeye Yönelik Sınıf Öğretmenlerinin Görüşlerinin İncelenmesi}

teaching students with hearing impaired against those who received such training. However, only two of all the teachers received training on students with hearing impaired. In fact, the majority of the teachers did not provide their students with support education and they did not receive adequate training on teaching students with hearing impaired. It has been determined that the students with hearing impaired of classroom teachers are doing applications such as using visual material, physical arrangement, providing class participation, speaking speed, tone, eye contact, poetry, song and drama participation to improve listening skills. Also, $65 \%$ of them stated that the area they needed assistance most to improve listening skills of their students with hearing impaired was communication. On the other hand, teachers need help with support training, device use, family support, unwanted behavior, writing, audio-visual material, reading, acoustic editing, drawing attention and teaching methods.

\section{Discussion}

In the light of past experiences of experienced teachers, it can be said that students with hearing impaired have positive opinions about improving their listening skills. The success of inclusive education for students with hearing impaired requires not only a positive approach of the primary school teachers to inclusive education, but also the basic knowledge of the impact of hearing loss on language development, classroom participation and academic achievement.

It has been determined that the students with hearing impaired of classroom teachers are doing applications such as using visual material, physical arrangement, providing class participation, speaking speed, tone, eye contact, poetry, song and drama participation to improve listening skills. In the process of education of students with hearing impaired some effective factors must be taken into account as class seating arrangement, use of FM radio systems, visual clues, eye contact, teachers to adjust the speed and tone of speech. It is important for teachers to know and use the appropriate methods and techniques to the conditions of the class level to improve listening skills.

The majority of the teachers do not provide support education to their students, and they do not receive adequate training. Based on the results of this study, it was understood that classroom teachers needed help in many subjects related to the education of students with hearing impaired. In order to increase the efficacy of teachers' competencies working with hearing impaired students, it is necessary that they receive adequate listening and communication skills training. In addition to the listening development, it is recommended to receive the necessary training through studies such as in-service training and seminars on issues such as the general education of these students, communication, development of other academic skills such as literacy, material preparation, teaching methods, device use, acoustic regulations, coping with undesired behavior, cooperation with the family. 